\title{
EFFECTS OF THE AGE OF GRAFTED LARVAE AND THE EFFECTS OF SUPPLEMENTAL FEEDING ON SOME MORPHOLOGICAL CHARACTERISTICS OF IRANIAN QUEEN HONEY BEES (Apis mellifera meda Skorikov, 1929)
}

\author{
Ali Mahbobi ${ }^{1}$, Mohammadbagher Farshineh-Adl ${ }^{2}$, \\ Jerzy Woyke ${ }^{3}$, Saeed Abbasi ${ }^{4}$
'Department of Animal Science, University of Zanjan, Zanjan, Iran
${ }^{2}$ Animal Science Research Institute, Karaj, Iran
${ }^{3}$ Apiculture Division, University of Life Sciences, Warsaw, Poland e-mail: jerzy_woyke@sggw.pl
${ }^{4}$ Department of Animal Science, University of Tehran, Karaj, Iran e-mail: saeedabbasi@ut.ac.ir

Received 01 December 2011; accepted 05 March 2012

$$
\mathrm{S} \text { u m m a r y }
$$

The research was conducted at the apiary of the Faculty of Agriculture, Zanjan University in Zanjan, Iran. Queens were reared in 24 Apis mellifera meda honey bee rearing colonies. The colonies were assigned to 4 grafting larvae age groups; 1 day old larvae, 2 day old larvae, and 3 day old larvae, and the last group reared emergency queen cells. The groups were divided into the 2 feeding groups: fed additionally and no fed. The effects of the age of the grafted larvae and the effects of supplemental feeding on 9 morphological characteristics of queens were measured. The results showed that the age of the larvae significantly affected the morphological characteristics of reared queens, and thus, their quality. Queens reared from 1 day old larvae were of the highest quality. These queens were significantly heavier $(158.83 \mathrm{mg})$ and had significantly larger spermatheca $\left(0.99 \mathrm{~mm}^{3}\right)$ than queens reared from larvae 2 and 3 days old. Queens from emergency queen cells were of lower quality than queens reared from 1 day old larvae. However, queens from emergency queen cells were of higher quality than queens reared from 3 day old larvae. The supplemental feeding significantly increased most morphological characteristics of the reared queens. The different ages of the larvae did not significantly affect the wing length nor did supplemental feeding affect the wing length.

Keywords: Apis mellifera meda, Iranian honey bee, grafting larvae, morphological characteristics, supplemental feeding, spermatheca volume, Iran.

\section{INTRODUCTION}

The quality of the queen bee determines the benefits received from honey bee colony. Various environmental factors affect the quality of the queen bees. These factors are: the age of the grafted larvae, origin of larvae, the number of young worker bees, food presence of starter and finisher colonies, and mated queen bees with enough drone bees (Morse, 1979). One of the methods of queen rearing is to rear queen bees in queen right colonies.
The method consists of raising combs of brood above a queen excluder in a strong colony, and grafting 12-18 h old larvae into queen cell cups next to the brood in the upper chamber (Wilkinson and Brown, 2002). Productivity of the queen bee depends on her age, breed, breeding term, weight at emergence, age of larvae, grafting methods, number of ovarioles, diameter of spermatheca, number of spermatozoa in the spermatheca, and if she has an anatomical disorder or not (Wen- 
Cheng and Chong-Yuan, 1985). One of the most important factors, affecting queen quality is the age of the larvae from which the queens were reared (Woyke, 1967).

Queens can be reared from worker larvae, in which the larvae are up to 3 days old, by grafting the larvae into artificial queen cell cups (Weiss, 1983; Dodologlu and Emsen, 1998). Larvae at any age up to the end of the third day have the potential of being reproductive queens. The quality of the queens decreases as the age of the grafted larvae increases. According to Woyke $(1967,1971)$ each 1 day increase in the age of the grafted larvae, decreased the body weight, the size of spermatheca, and the number of ovarioles in the ovaries of the queen. Rawash et al. (1983) found that virgin queens reared from larvae 1 day old were the heaviest and queens reared from 3 day old larvae were the lightest. Tarpy et al. (2011) verified that low-quality queens are indeed produced from older worker larvae, as measured morphometrically and as measured by stored sperm counts.

The native honey bee in Iran is Apis mellifera meda. Engel (1999) calls this bee - The Median Honey Bee. It is most common in Iran and Iraq but does range into southeastern Turkey and northern Syria. Not much is known about this bee. We conducted this experiment to determine the effects of the age of grafted larvae and the effects of supplemental feeding on the quality of the Iranian queen bees $A$. m. meda.

\section{MATERIALS AND METHODS}

This research was conducted in May and June 2007 at the apiary of the Agriculture faculty of Zanjan University in Zanjan, Iran. We selected 24 Iranian honey bee colonies (A. m. meda) of the same strength, headed by 1 year old queens. The colonies were randomly assigned to 4 grafting larvae age groups; 1 day old larvae, 2 day old larvae and 3 day old larvae and colonies rearing emergency queen cells (Feel and Morse, 1984). All the groups were divided into 2 feeding groups; fed and not fed. The colonies were fed with pollen supplement (sugar powder, milk meal powder and honey, 2:2 and 1 respectively) 3 weeks before grafting and this was continued until the queen cells were sealed. Queen rearing colonies were created $24 \mathrm{~h}$ prior to grafting by removing the queens. An Iranian breeder colony was selected from breeder stock in the apiary by evaluating colony records. The queen of the breeder colony was confined on 3 empty combs by perpendicular queen excluders. The confinement was done to provide larvae for grafting in which the age of the larvae was known. A grafting frame of two bars carrying 24 artificial queen cell cups was used. Per 8 larvae of the three age groups; 1 day old, 2 day old, and 3 day old were grafted into the queen cell cups wetted with a drop of water with royal jelly (1:1) solution. One day before the emergence of the virgin queens, mature queen cells in each starter-finisher colony were transferred to the banking frames with individual chambers. The newly emerged queens were immediately killed. The following morphological characteristics were measured: (1) Wet weight: the queens were weighed to the nearest $0.1 \mathrm{mg}$; (2) External body characteristics: head width (W), head length (L), thorax W., thorax L., wing W., wing L. and cubital index. (3) Internal body characteristics: length and width of the spermatheca, which in queens reared from older larvae is not a ball but an ellipsoid. A micrometer eyepiece was used to measure the body characteristics.

Next, the volume of spermatheca (SV) was calculated according to the formula:

$\mathrm{SV}=(4 / 3)(\pi)\left(\mathrm{r}^{3}\right)[\mathrm{r}=$ average radius of the $r$ for the length and the $r$ for the width of the spermatheca] (Hatch et al., 1999).

\section{Statistical analyses}

The data were analyzed by the ANOVA procedure to determine the effect of the age of the grafted larvae and the effect of the supplemental feeding on queen quality. Duncan multiple comparison test was used to compare the means $(\mathrm{p}<0.05)$. 


\section{RESULTS}

\section{Larval age}

The effects of the age of the grafted larvae on some characteristics of queens reared from 1 day old larvae, 2 day old larvae and 3 day old larvae and from emergency queen cells are recorded in Table 1. The mean values of the 9 morphological characteristics of queens reared from 1 day old larvae were significantly higher $(\mathrm{P}<0.05)$ than the 3 characteristics (weight, wing $\mathrm{W}$. and spermatheca volume) of queens reared from 2 day old larvae, and than the 5 characteristics (weight, head W., thorax L., cubital index and spermatheca volume) of queens reared from 3 day old larvae. Two mean values of the characteristics; the weight of the queens $(158.83 \mathrm{mg})$ and the volume of spermatheca $\left(0.99 \mathrm{~mm}^{3}\right)$ were significantly higher than those of queens reared from both, 2 and 3 day old larvae.

The mean values of the 9 characteristics of queens reared from 2 day old larvae were significantly higher than the 3 characteristics (weight, thorax L. and spermatheca) of queens reared from 3 day old larvae.

The means of the wing length of queens reared from larvae of all the three different ages, were not found to differ significantly.

The mean values of morphological characteristics of queens reared from the emergency queen cells were significantly lower than the 2 characteristics (head L. and wing W.) of queens reared from 1 day old larvae, and than the 1 characteristic (head L.) of queens reared from 2 day old larvae. However, the means of the emergency queens were significantly higher than the 6 characteristics (weight, head W., thorax W., thorax L., cubital index and spermatheca) of queens reared from 3 day old larvae. This indicates that the quality of emergency queens was lower than that of queens reared from 1 day old larvae, yet higher than that of queens reared from 3 day old larvae.

\section{Supplemental feeding}

Table 2 shows that supplemental feeding significantly affected most of the morphological characteristics of the queens $(\mathrm{P}<0.05)$. However, no significant effect on wing length of reared queens was found.

\section{DISCUSSION}

We successfully produced queens of varying quality by rearing them from worker larvae of different ages. Queens reared from older larvae were smaller and thus, according to Avetisyan (1961) and Makarov (1969), less fecund. Furthermore, initial larvae age affected queen weight and spermatheca size. These features, in turn, are correlated with the number of spermatozoa that a queen acquires during natural mating (Woyke, 1966). Queen bees reared from

Table 1 .

Characteristics of queens reared from different aged larvae and from emergency queen cells

\begin{tabular}{|c|c|c|c|c|c|c|c|c|c|c|}
\hline \multirow{2}{*}{$\begin{array}{c}\text { Age } \\
\text { of } \\
\text { larvae }\end{array}$} & \multirow[b]{2}{*}{$\begin{array}{c}\text { No. } \\
+\end{array}$} & \multicolumn{9}{|c|}{ 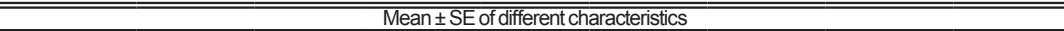 } \\
\hline & & $\begin{array}{l}\text { Weight } \\
\text { mg }\end{array}$ & $\begin{array}{c}\text { Head } \\
W^{*}{ }^{*} \mathrm{~mm}\end{array}$ & $\begin{array}{c}\text { Head } \\
\text { L.. }{ }^{*} \mathrm{~mm}\end{array}$ & $\begin{array}{l}\text { Thorax } \\
\text { W. } \mathrm{mm}\end{array}$ & \begin{tabular}{|l|} 
Thorax \\
L. $\mathrm{mm}$
\end{tabular} & \begin{tabular}{|c|} 
Wing \\
W.mm
\end{tabular} & $\begin{array}{l}\text { Wing } \\
\text { L. mm }\end{array}$ & $\begin{array}{l}\text { Cubital } \\
\text { index }\end{array}$ & $\begin{array}{c}\text { Sperma- } \\
\text { theca } \mathrm{mm}^{3}\end{array}$ \\
\hline 1 day & 47 & $158.83 \pm 2.31 a$ & $3.84 \pm 0.02 a$ & $3.61 \pm 0.03 a$ & $4.19 \pm 0.03 a b$ & $4.04 \pm 0.03 a$ & $3.33 \pm 0.02 a$ & $10.36 \pm 0.03 a$ & $3.01 \pm 0.06 a b$ & $0.99 \pm 0.02 a$ \\
\hline 2 days old & 38 & $150.94 \pm 2.51 \mathrm{bc}$ & $3.82 \pm 0.03 \mathrm{ab}$ & $3.60 \pm 0.03 a$ & $4.19 \pm 0.03 a b$ & $4.03 \pm 0.04 a$ & $3.25 \pm 0.03 b$ & $10.06 \pm 0.25 a$ & $2.83 \pm 0.08 \mathrm{bc}$ & $0.88 \pm 0.02 b$ \\
\hline 3 days old & 45 & $144.58 \pm 2.97 \mathrm{c}$ & $3.75 \pm 0.03 \mathrm{~b}$ & $3.54 \pm 0.04 a$ & $4.11 \pm 0.04 \mathrm{~b}$ & $3.91 \pm 0.04 b$ & $3.27 \pm 0.03 \mathrm{ab}$ & $10.27 \pm 0.05 a$ & $2.80 \pm 0.07 \mathrm{c}$ & $0.78 \pm 0.03 \mathrm{c}$ \\
\hline Emergency & 43 & $156.56 \pm 2.99 \mathrm{ab}$ & $3.85 \pm 0.02 \mathrm{a}$ & $3.39 \pm 0.04 b$ & $4.22 \pm 0.03 a$ & $4.03 \pm 0.03 \mathrm{a}$ & $3.22 \pm 0.03 \mathrm{~b}$ & $10.30 \pm 0.06 \mathrm{a}$ & $3.17 \pm 0.07 a$ & $0.97 \pm 0.02 \mathrm{a}$ \\
\hline
\end{tabular}

q- queens, * W - width, L - length. Means with different letters are significantly different $\mathrm{P}<0.05$.

Table 2 .

Effect of supplemental feeding on morphological characteristics of reared queens

\begin{tabular}{||c|c|c|c|c|c|c|c|c|c|c|}
\hline \multirow{2}{*}{ Treatment } & \multirow{2}{*}{$\begin{array}{c}\text { No. } \\
+\end{array}$} & \multicolumn{10}{|c|}{$\begin{array}{c}\text { Weight } \\
\mathrm{mg}\end{array}$} & $\begin{array}{c}\text { Head } \\
\text { W.* } \mathrm{mm}\end{array}$ & $\begin{array}{c}\text { Head } \\
\text { L.* mm }\end{array}$ & $\begin{array}{c}\text { Thorax } \\
\text { W. } \mathrm{mm}\end{array}$ & $\begin{array}{c}\text { Thorax } \\
\text { L. mm }\end{array}$ & $\begin{array}{c}\text { Wing } \\
\text { W. mm }\end{array}$ & $\begin{array}{c}\text { Wing } \\
\text { L.mm }\end{array}$ & $\begin{array}{c}\text { Cubital } \\
\text { index }\end{array}$ & $\begin{array}{c}\text { Sperma- } \\
\text { theca mm3 }\end{array}$ \\
\hline Feeding & 93 & $159.82 \pm 1.54 \mathrm{a}$ & $3.88 \pm 0.02 \mathrm{a}$ & $3.59 \pm 0.02 \mathrm{a}$ & $4.25 \pm 0.02 \mathrm{a}$ & $4.07 \pm 0.02 \mathrm{a}$ & $3.22 \pm 0.03 \mathrm{a}$ & $10.29 \pm 0.10 \mathrm{a}$ & $3.03 \pm 0.05 \mathrm{a}$ & $0.94 \pm 0.02 \mathrm{a}$ \\
\hline No feeding & 80 & $144.69 \pm 2.56 \mathrm{~b}$ & $3.74 \pm 0.02 \mathrm{~b}$ & $3.48 \pm 0.02 \mathrm{~b}$ & $4.10 \pm 0.03 \mathrm{~b}$ & $3.92 \pm 0.31 \mathrm{~b}$ & $3.33 \pm 0.02 \mathrm{~b}$ & $10.21 \pm 0.04 \mathrm{a}$ & $2.87 \pm 0.06 \mathrm{~b}$ & $0.87 \pm 0.02 \mathrm{~b}$ \\
\hline
\end{tabular}

$q$ - queens, * W - width, $\mathrm{L}$ - length. Means with different letters are significantly different $\mathrm{P}<0.05$. 
1 day old larvae were heavier at emergence and had larger spermatheca than other groups. Woyke (1971) found a negative relationship between grafting age and several characteristics, including ovariole number and spermatheca volume. Gilly et al. (2003) produced variation among the quality of related morphological traits by rearing queen from worker larvae of different ages. Many of these traits correlated with each other.

Supplemental feeding affected queen quality. Król et al. (1992) concluded that queens reared in colonies which were fed with sugar syrup supplemented with vitamin $B$, were $11 \%$ heavier and had $6 \%$ more ovarioles. However, Gençer et al. (2000) did not confirm this. The abundance of pollen sources in the experimental area at the grafting period may have concealed the impact of supplements in the sugar syrup. On the other hand, the weight of queen was affected by the age of larvae (Gençer et al., 2000; Kahya and Gencer, 2006). Both, larval and adult nutrition also affected the ovary development of the queens (Hoover et al., 2006). Underfeeding of larvae resulted in smaller bees (Jay, 1964). The differentiation of queen and worker is achieved through nutrition. It is the quality and quantity of the food received by the larvae that determines the development of the two castes.

Because during our queen rearing, the flow of nectar and pollen were weak, supplemental feeding significantly affected different queen characteristics. Queens reared from emergency queen cells were of lower quality than queens reared from the 1day old larvae.

Honey bees rear swarming queens from eggs that hatch in special queen cells. However, in queenless colonies, workers rear queens in emergency queen cells, which are modified worker cells containing 2 day old larvae (Winston, 1987). Queens reared from worker larvae older than 1 day, are morphometrically more similar to workers than are queens reared from young larvae. Adult queens reared from older larvae typically have smaller exoskeletons and reproductive organs (Woyke, 1971). Our finding concerning $A$. m. meda are similar to those of $A$. m. mellifera reported by Woyke (1967, 1971), Tarpy et al. (2000), Gilley et al. (2003) and Tarpy et al. (2011).

\section{CONCLUSIONS}

1. Age of grafted larvae significantly affects some characteristics of Iranian queen bees, Apis mellifera meda.

2. The queens reared from 1 day old larvae are significantly heavier and have larger spermatheca, than queens reared from 2 and 3 day old larvae.

3. Emergency queens are of lower quality than queens reared from larvae 1 day old, however they are of higher quality than queens reared from 3 day old larvae.

4. The supplemental feeding significantly affects most of the morphological characteristics.

5. Different age of larvae as well as supplemental feeding does not significantly affect wing length.

\section{ACKNOWLEDGMENTS}

We wish to thank Abbas Gerami, Jalal Jalali Zonoz, Morad Pasha Eskandari Nasab, Davood Zahmztkesh, Mojtaba Ramjerdian and Mehdi Darzi for their assistance and we wish to thank Eman Nemati and Ahmad Ostovari for their guidance in the statistical analysis.

\section{REFERENCES}

Avetisyan G. (1961) - The relation between interior and exterior characteristics of the queen and fertility and productivity of the bee colony. Proceedings of $18^{\text {th }}$ Apimondia congress, Spain, Madrid: 44-53.

Dodologlu A., Emsen B. (1998) Relationship between larvae age and characteristics of queen honeybee (Apis mellifera L.) after single and double grafting. J. Vet. and Anim. Sci., 21: 379-385.

Engel M. S. (1999) - The taxonomy of recent and fossil honey bee (Hymenoptera: Apidae; Apis). J. Hym. Res., 8(2): 165-196. 
Feel R. D., Morse R. A. (1984) Emergency queen cell production in the honeybee colony. Insectes Soc., 31: 221-237.

Gençer H. V., Qasim Shah S. Firatli Ç. (2000) - Effects of supplemental feeding of queen rearing colonies and larval age on the acceptance of grafted larvae and queen traits. J. Biol. Sci., 3(8): 1319-1322.

Gilley D. C., Tarpy D. R., Land B. B. (2003) - Effect of queen quality on interactions between workers and dueling queens in honeybee (Apis mellifera L.) colonies. Behav. Ecol. Sociobiol., 55: 190-196.

Hatch S., Tarpy D. R., Fletcher D. J. C. (1999) - Worker regulation of emergency queen rearing in honey bee colonies and the resultant variation in queen quality. Insectes Soc., 46: 372-377.

Hoover, S. E. R., Higo H. A., Wiston M. L. (2006) - Worker honey bee ovary development: Seasonal variation and the influence of larval and adult nutrition. J. Comp. Physiol., 176: 55-63.

Jay S. C. (1964) - Starvation studies of larval honey bees. Can. J. Zool., 48:169-173.

Kahya Y., Gencer V. (2006) - The weight changes and reproductive traits of honeybee queens A. m. caucasica. Proceedings of Second European Conference of Apidology, Czech Republik, Prague, 10-14 September 2006: 56-57.

Król A., Hartwig A., Topolska G. (1992) - Quality of queens reared in colonies receiving sugar supplemented with vitamin B. $_{1}$ Pszczel. Zesz. Nauk., 36: 32-40. (in Polish, English summary).

Makarov Y. I. (1969) - Dissertation: biologically and economically useful character of far eastern bees and their selection. Timiryazev Academy of Agriculture, Moscow.

Morse R. A. (1997) - Rearing queen honeybee. Wicwas pres, Ithaca, New York, 128 pp.
Rawash I., Gayarfh E., Helalyms E. (1983) - Effect of larval age and number of cell cups on the quality of Cario-Egyption F1 hybrid of honeybee queens. Apic. Abst., 36(3): 925/85.

Tarpy D. R., Hatch S., Fletcher D. J. C. (2000) - The influence of queen age and quality during queen replacement in honey bee colonies. Anim. Behav., 59: 97-101.

Tarpy D. R., Keller J. J., Caren J. R., Delaney D. A. (2011) - Experimentally induced variation in the physical reproductive potential and mating success in honey bee queens. Insectes Soc., 58: 569-574.

Weiss K. (1983) - The influence of rearing conditions on queen development. In: F. Ruttner (Ed.) Queen rearing biological basis and technical instruction: 83-177.

Wen-Cheng H., Chong-Yuan Z. (1985) - The relationship between the weight of queen honeybee at various stages and the number of ovarioles, eggs laid and sealed brood produced. Honey Bee Science, 6(3): 113-116.

Wilkinson D., Brown M. A. (2002) Rearing queen honey bees in a queenright colony. Am. Bee J., 142(4): 270-274.

Winston M. L. (1987) - The biology of the honeybee. Harvard University Press, Cambridge, MA., 281 pp.

Woyke J. (1966) - Wovon hängt die Zahl der Spermien in der Samenblase der auf natürlichem Wege begatteten Königinnen ab., Z. Bienenforsch., 8: 236-247.

Woyke J. (1967) - Rearing conditions and number of sperms reaching the queens spermatheca. Proceedings of $21^{\text {th }}$ Apimondia congress, Univ. Maryland, USA, 14 - 17 August, 1967: 232-234.

Woyke J. (1971) - Correlation between the age at which honeybee brood was grafted, characteristics of the resultant queens and result of insemination. J. Apic. Res., 10(1): 45-55. 


\section{WPLYW WIEKU LARW UŻYTYCH DO WYCHOWU \\ I DODATKOWEGO KARMIENIA NA NIEKTÓRE CECHY MORFOLOGICZNE PSZCZÓŁ PERSKICH (Apis mellifera meda Skorikov, 1929)}

Mahbobi A., Farshineh-Adl M. B., Woyke J., Abbasi S.

S t r e s z c z e n i e

Badania prowadzono w pasiece Wydziału Rolnictwa Uniwersytetu Zanjan w Zanjan w Iranie. Matki pszczele wychowywano w 24 rodzinach pszczół perskich Apis mellifera meda. Porównywano matki wychowywane z larw 1-no, 2-wu i 3 dniowych oraz z mateczników ratunkowych. Połowę matek z wszystkich grup wychowywano w rodzinach nie podkarmanych, a drugą w podkarmianych ciastem białkowym. Wpływ wieku larw oraz podkarmiania oceniano przez pomiar 9 cech morfologicznych wychowanych matek. Wiek larw z których wychowywano matki, wpłyną istotnie na cechy, a tym samym na wartość matek. Najbardziej wartościowe były matki wychowane z larw 1-no dniowych. Matki te były istotnie cięższe $(158,83 \mathrm{mg})$ oraz miały istnie większy zbiorniczek $\left(0,99 \mathrm{~mm}^{3}\right)$, niż wychowane z larw 2 i 3 dniowych. Matki z mateczników ratunkowych były gorszej jakości niż wychowane z larw 1-no dniowych, lecz były lepsze, niż wychowane $\mathrm{z}$ larw 3 dniowych. Dodatkowe podkarmianie zwiększyło istotnie większość cech morfologicznych wychowanych matek. Zarówno różny wiek larw użytych do wychowu jak i dodatkowe podkarmianie nie wpłynęły istotnie na długość skrzydeł wychowanych matek.

Słowa kluczowe: Apis mellifera meda, pszczoła perska, przekładanie larw, cechy morfologiczne pszczół, podkarmianie uzupełniające, zbiorniczek nasienny, Iran. 